\title{
Reverse Osmosis Performance in MBR-RO Process with Recirculation of RO Concentrate to MBR for Water Reclamation
}

\author{
Hui Deng, Matthieu Jacob, Manon Montaner, Jean-Stéphane Pic, Christelle Guigui* \\ TBI, Université de Toulouse, CNRS, INRA, INSA, Toulouse, France \\ Email: ${ }^{*}$ guigui@insa-toulouse.fr
}

How to cite this paper: Deng, H., Jacob, M., Montaner, M., Pic, J.-S. and Guigui, C. (2020) Reverse Osmosis Performance in MBR-RO Process with Recirculation of RO Concentrate to MBR for Water Reclamation. Journal of Water Resource and Protection, 12, 800-824.

https://doi.org/10.4236/jwarp.2020.129047

Received: May 12, 2020

Accepted: September 27, 2020

Published: September 30, 2020

Copyright $\odot 2020$ by author(s) and Scientific Research Publishing Inc. This work is licensed under the Creative Commons Attribution International License (CC BY 4.0).

http://creativecommons.org/licenses/by/4.0/

(c) (i) Open Access

\begin{abstract}
An integrated membrane system, membrane bioreactor-reverse osmosis (MBR-RO), has become highly efficient in producing high-quality water for municipal wastewater reclamation. However, disposal of a highly concentrated waste stream ( $\mathrm{RO}$ concentrate or $\mathrm{RO}$ retentate) generated in this combination is an important issue. This work investigated $\mathrm{RO}$ behaviour in an integrated pilot scale MBR-RO system for municipal wastewater reuse with the continuous recycling of RO retentate to the MBR influent. RO membrane retention and the fouling propensity were studied. $\mathrm{RO}$ concentrate, produced by the RO process at a fixed concentration factor (CF) of 3 , was recycled continuously to the MBR, leading to water recovery of the entire process around 92\%. Osmotic pressure model, saturation index method, high performance liquid chromatography equipped with size exclusion column (HPLC-SEC) and specific filtration test were used to analyse the fouling potential of the RO membrane. The results obtained showed that even though RO concentrate recycling changed remarkably, the compositions of both MBR permeate and $\mathrm{RO}$ concentrate, the quality of RO permeate remained almost constant in terms of organic matters, conductivity, and ionic salts. However, these high concentrations of organic or inorganic substances in $\mathrm{RO}$ concentrate were major factors leading to the $\mathrm{RO}$ membrane fouling. Before $\mathrm{RO}$ concentrate recycling, a decline of approximately $30 \%$ of the initial RO permeate flux was observed in the period when the CF was increasing to 3 , mainly due to the osmotic pressure effect of retained ions and the deposits of organic matters at the RO membrane surface. After RO concentrate addition to the MBR, due to the continuous accumulation of ionic salts on the RO membrane surface, a gradual reduction in RO permeate flux (additional 19\%) was also mainly attributed to the osmotic pressure effect of the retained ions. These observations showed that the continuous addition of RO concentrate to the MBR was successful in a combined MBR and RO process in terms of the excellent qual-
\end{abstract}


ity of RO permeate.

\section{Keywords}

High-Quality Water Reuse, MBR-RO Combination, RO Concentrate Recirculation, RO Fouling

\section{Introduction}

At present, MBR followed by an RO process (MBR-RO) has gained worldwide acceptance as the most important technology in municipal wastewater reuse [1] [2] [3] [4]. However, membrane fouling is the main limitation in the application of this integrated system for municipal wastewater reuse, due to an increase in operation and maintenance costs by reducing the RO membrane performance and its service lifetime. The RO membrane fouling is a complicated phenomenon, which is prone to occur in different forms (inorganic scaling, organic fouling, biofilm and colloidal fouling) [5]. The constituents of MBR permeate as RO feed, including inorganic ions and organic matters, are mainly associated with how fouling develops in the RO membrane. Soluble microbial products (SMPs) present in MBR permeate are found to be important constituents leading to RO membrane fouling [6]. The presence of inorganic salts in MBR permeate also leads to a reduction in RO permeate flux in MBR-RO systems for real domestic wastewater reuse [7] [8]. Jacob et al. (2010) found that MBR effluent containing less concentrated organic matters and conductivity exhibits a lower reduction in RO permeate flux than more concentrated MBR effluent. Moreover, the concentration factor (CF) is a key parameter for $\mathrm{RO}$ membrane fouling behaviour. These findings demonstrate the important role of the characteristics of MBR permeate in the fouling mechanisms of the RO membrane.

In addition to RO membrane fouling, the disposal of the $\mathrm{RO}$ concentrate stream (also known as RO retentate) is still an ultimate challenge for the sustainable application of an RO process for the reclamation of secondary effluent, because RO concentrate contains a broad range of inorganic and organic constituents at elevated concentrations, such as ionic salts, organic matters, and refractory organic compounds ([9] [10] [11]). The concentration of the retained constituents in RO concentrate is observed to be at least twice that in the wastewater treatment plants (WWTPs) effluent as RO feed water [12]. Several studies have shown that the direct discharge of RO concentrate to the environment may be associated with a risk of toxicity for aquatic organisms [13] [14]. By employing the Microtox ${ }^{\circledast}$ assay, Zhou et al. (2011) observe that raw RO concentrate from municipal wastewater reclamation appears to be toxic with $62 \%$ inhibition for Vibrio fischeri. Therefore, it is of importance to establish beneficial reuse strategies for RO concentrate management.

To minimize the quantity of untreated RO concentrate directly discharged into the environment, a possible strategy is to recirculate $\mathrm{RO}$ concentrate to the 
preceding MBR unit. In earlier research [15], nanofiltration (NF) concentrate is returned back into an activated sludge bioreactor for the treatment of dumpsite leachates. The elimination rate of chemical oxygen demand (COD), as an indicator for the treatment efficiency, is enhanced in the recycling phase. In the last five years, a few researchers have extended their work to investigate the performance of an MBR-NF system for wastewater treatment with NF concentrate recycling to the MBR process, by considering the fouling potential of the membrane in MBR and of the NF membrane, and the quality of NF permeate. Li et al. (2016) apply an MBR coupled with an NF membrane in cross-flow mode to treat wastewater from antibiotic production, where NF concentrate is recycled back to the MBR unit [16]. Their results demonstrate that the MBR-NF process is successful in treating the antibiotic wastewater with NF concentrate recirculation, achieving a high water recovery higher than $92 \%$ and an excellent water quality that meets the standard for industrial use. On the other hand, ionic salts and SMPs brought by NF concentrate recirculation are two main constituents that result in severe membrane fouling in MBR. In addition, the accumulation of non-biodegradable organic components in NF concentrate exhibits a remarkable impact on NF membrane fouling [16]. Before NF process, pre-treatment, including activated carbon, advanced oxidation process (AOPs) and coagulation, has been proposed to reduce membrane fouling [17]. In the case of municipal wastewater reclamation, Kappel et al. (2014) compare the performance of an NF process (dead-end mode) treating MBR permeate without or with NF concentrate recirculation to the MBR unit. Results have demonstrated that accumulated salts and small organics molecule in the NF concentrate have no impact on the quality of NF permeate. However, the recirculation of NF concentrate to MBR influences the scaling potential of the NF membrane. Inorganic substances are the main components govern NF membrane fouling [18].

In comparison with an NF membrane, an $\mathrm{RO}$ membrane has a higher rejection potential for ionic salts and organic substances with smaller molecule size, and it is less prone to permeate flux decline due to internal fouling [3]. Thus, in this work, the RO membrane was selected to improve water quality, and the RO concentrate produced was continuously returned to the MBR unit in the aim of reducing their volume. RO retentate addition to MBR could increase a load of inorganic and organic substances, further affecting the fouling potential of the organic MF membrane in MBR (PET membrane with a mean pore size equal to $0.4 \mu \mathrm{m}$ ) [19]. Moreover, high salinity might promote the release of organic cellular constituents by accelerating the endogenous respiration of microorganisms in the MBR [20]. Consequently, organic substances such as protein-like and polysaccharide-like substances in MBR permeate possibly induce RO membrane fouling. In addition, $\mathrm{Ca}^{2+}$-induced organic fouling could promote $\mathrm{RO}$ permeate flux decline through interaction with the negatively charged group of organic matters at the RO membrane surface [6]. Joss et al. (2011) make the first attempt to recycle treated RO concentrate by ozonation back to the MBR unit in the 
MBR-RO-ozonation system, aiming to improve the quality of MBR effluent with a water yield of $90 \%$. This combination is sufficient to reduce emerging micropollutants to below the detection limit and to retain inorganic salts [21]. However, the contribution of organic matters brought by $\mathrm{RO}$ concentrate to the $\mathrm{RO}$ membrane fouling is not investigated.

In this context, the main objective of the present article was to elucidate the performance of the RO process for treating MBR permeate when raw RO concentrate was continuously recirculated to the MBR. The efficiency of the RO membrane to retain common substances and its fouling propensity were studied. For this purpose, an MBR combined with a cross-flow RO process was used with $\mathrm{RO}$ concentrate recycling to the $\mathrm{MBR}$, where $\mathrm{RO}$ concentrate represented one-fifth of the total feed flow of MBR unit. The retention efficiencies of organic compounds and ionic salts by the RO membrane was addressed before and during $\mathrm{RO}$ concentrate recirculation. Meanwhile, the fouling potential of the RO membrane was examined by the variation of the RO permeate flux versus operating time, the osmotic pressure model of retained salts, the saturation index (SI) of mineral salts, and the analysis of compositions of RO concentrate.

\section{Materials and Methods}

\subsection{MBR Permeate Characteristics}

MBR permeate was obtained from a lab-scale MBR pilot treating municipal wastewater. Prior to RO concentrate recirculation, the MBR was operated for six weeks to achieve stable performance. The characteristics of the municipal wastewater and of MBR permeate produced first without and then with $\mathrm{RO}$ concentrate recirculation are given in Table 1 . The MBR was effective in removing organic matters, with $\sim 97 \%$ removal for dissolved organic carbon (NPOC). As expected, the elimination of inorganic salts by MBR was poor, which meant that most of the ionic salts were still present in MBR permeate. During RO concentrate recycling to the MBR, the quality of MBR permeate (as RO feed) is shown in Table S1 (see Supplementary Information).

\subsection{MBR-RO Treatment Schema}

Figure 1 depicts the pilot-scale MBR-RO system where RO retentate was recirculated to the MBR. The MBR system consisted of an anoxic reactor (5.4 L) and an aerobic reactor $(12.6 \mathrm{~L})$ with a submerged flat-sheet MF membrane $(0.2 \mu \mathrm{m}$ pore size, $0.1 \mathrm{~m}^{2}$ surface area, Kubota, Japan), as described in previous articles [19] [22] MBR permeate, produced at a flow rate of $23.6 \mathrm{~L} \cdot \mathrm{d}^{-1}$, was first stored in a tank for RO tests. The principal operating parameters of the MBR pilot are listed in Table S2.

The cross-flow RO pilot consisted of a storage tank with a useful volume of 50 L, a feed pump (Moineau PCM), a rectangular stainless steel filtration cell with an effective membrane surface area of $0.051 \mathrm{~m}^{2}$, a recirculation loop with a volume of $0.8 \mathrm{~L}$, a pressure-regulating valve and several digital flowmeters, as depicted 
Table 1. Compositions of wastewater and RO feed (MBR permeate) without RO concentrate recycling to $\mathrm{MBR}$.

\begin{tabular}{cccc}
\hline Parameter & Unit & Wastewater & RO feed (before recycling) \\
\hline $\mathrm{pH}$ & - & $-^{\mathrm{a}}$ & 8.1 \\
Conductivity & $\mu \mathrm{S} \cdot \mathrm{cm}^{-1}$ & - & $1268 \pm 26$ \\
$\mathrm{NPOC}^{\mathrm{b}}$ & $\mathrm{mg} \cdot \mathrm{L}^{-1}$ & $231 \pm 5$ & $5.8 \pm 0.1$ \\
Proteins & $\mathrm{mg} \cdot \mathrm{L}^{-1}$ & $33.4 \pm 3.3$ & $6.5 \pm 1.3$ \\
Polysaccharide & $\mathrm{mg} \cdot \mathrm{L}^{-1}$ & $7.4 \pm 0.7$ & $1.0 \pm 0.1$ \\
$\mathrm{COD}^{\mathrm{c}}$ & $\mathrm{mg} \cdot \mathrm{L}^{-1}$ & $830 \pm 10$ & $21 \pm 2$ \\
$\mathrm{UVA}_{254}{ }^{\mathrm{d}}$ & $\mathrm{cm}{ }^{-1}$ & - & $0.152 \pm 0.002$ \\
$\mathrm{UVA}_{280}$ & $\mathrm{~cm}{ }^{-1}$ & - & $0.118 \pm 0.002$ \\
$\mathrm{DIC}^{\mathrm{e}}$ & $\mathrm{mg} \cdot \mathrm{L}^{-1}$ & - & $6.5 \pm 0.1$ \\
$\mathrm{Cl}^{-\mathrm{f}}$ & $\mathrm{mg} \cdot \mathrm{L}^{-1}$ & $64 \pm 6$ & $127 \pm 13$ \\
$\mathrm{~N}^{-\mathrm{NO}_{3}^{-}}$ & $\mathrm{mg} \cdot \mathrm{L}^{-1}$ & $0.20 \pm 0.02$ & $5.0 \pm 0.5$ \\
$\mathrm{HCO}_{3}^{-}$ & $\mathrm{mg} \cdot \mathrm{L}^{-1}$ & - & $27 \pm 3$ \\
$\mathrm{SO}_{4}^{2-}$ & $\mathrm{mg} \cdot \mathrm{L}^{-1}$ & $42 \pm 4$ & $43 \pm 4$ \\
$\mathrm{P}^{-\mathrm{PO}_{4}^{3-}}$ & $\mathrm{mg} \cdot \mathrm{L}^{-1}$ & $3.0 \pm 0.3$ & $0.90 \pm 0.09$ \\
$\mathrm{Na}^{+}$ & $\mathrm{mg} \cdot \mathrm{L}^{-1}$ & $174 \pm 17$ & $176 \pm 18$ \\
$\mathrm{~K}^{+}$ & $\mathrm{mg} \cdot \mathrm{L}^{-1}$ & $14 \pm 1$ & $12 \pm 1$ \\
$\mathrm{Mg}^{2+}$ & $\mathrm{mg} \cdot \mathrm{L}^{-1}$ & $8.4 \pm 0.8$ & $70 \pm 7$ \\
$\mathrm{Ca}^{2+}$ & $\mathrm{mg} \cdot \mathrm{L}^{-1}$ & $124 \pm 12$ & \\
\hline & & & \\
\hline
\end{tabular}

${ }^{a}$ not analysed. bNPOC: non-purgeable dissolved organic carbon. ${ }^{\mathrm{c}} \mathrm{COD}$ : chemical oxygen demand. ${ }^{\mathrm{d}} \mathrm{UV}$ : ultra-violet absorbance. ${ }^{e} \mathrm{DIC}$ : dissolved inorganic carbon. ${ }^{\mathrm{f}}$ for MBR permeate, the amount of $\mathrm{Cl}^{-}$introduced by $\mathrm{RO}$ feed $\mathrm{pH}$ control was also included.

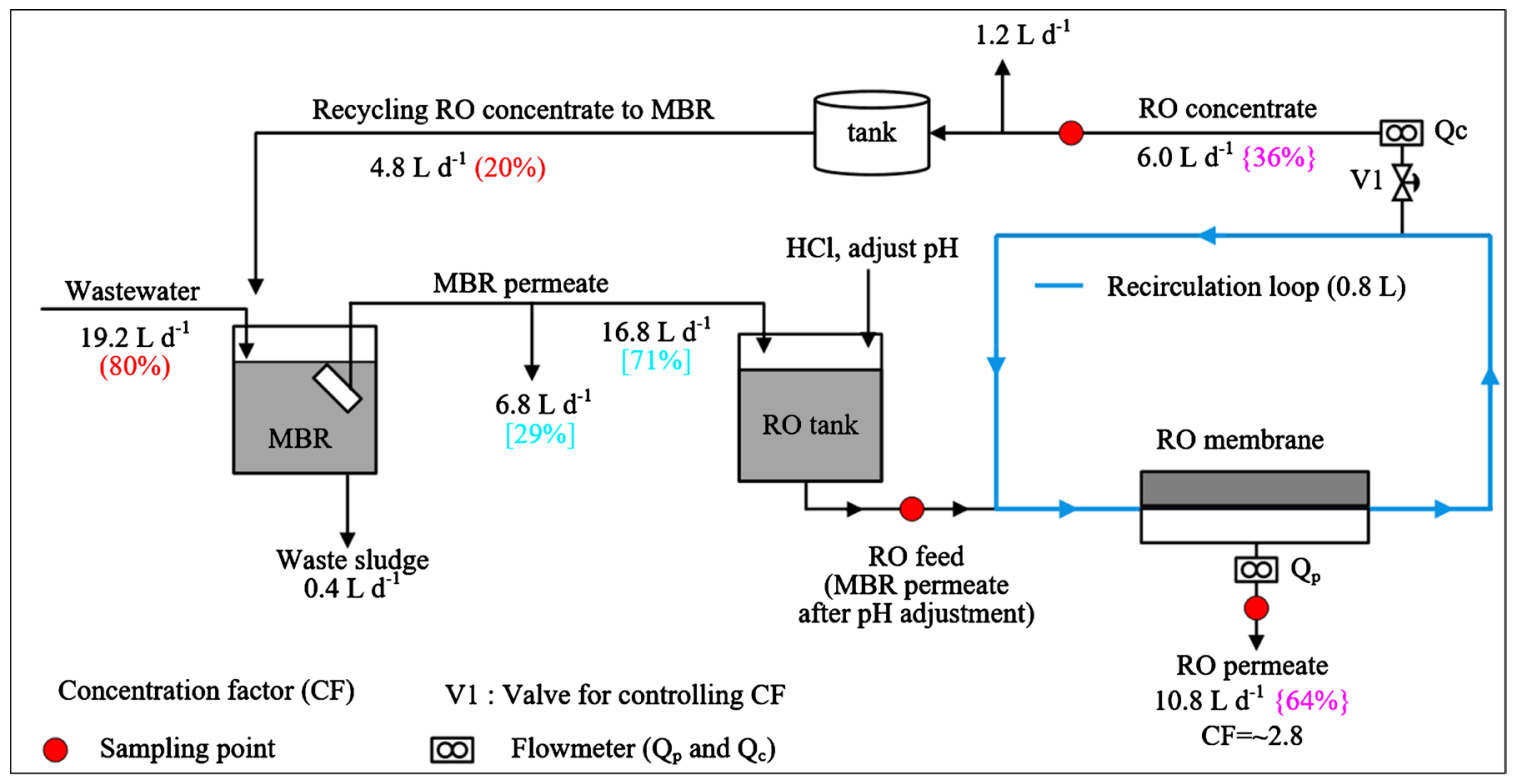

Figure 1. Schema of cross-flow RO pilot with recirculation of RO concentrate to the MBR unit. (\%): MBR influent consisted of $80 \%$ wastewater and $20 \%$ RO concentrate. [\%]: $71 \%$ of MBR permeate flow was used as RO feed water. $\{\%\}:$ The recovery of RO process: $64 \%$. The recovery of the entire process: $92 \%$. 
in Figure 1. A flat-sheet RO membrane (ESPA2, Hydranautics) was used in this work, and the relevant properties are shown in Table S3. Before the treatment of MBR permeate, the ESPA2 membrane was compacted for at least $2 \mathrm{~h}$ with distilled water at a fixed pressure (10 bar) until the RO permeate flux was stable. Regarding the operation of the RO pilot, firstly, valve $V_{1}$ was closed to ensure the concentration of substances in the recirculation loop. During this period, the concentration factor (CF) was followed through the measured conductivity in both the RO feed and the RO concentrate (Equation (1)). After that, the flow rate $\left(Q_{c}\right)$ of $\mathrm{RO}$ concentrate was regulated by a valve $\left(V_{1}\right)$ so as to enable the RO pilot to work at a fixed volumetric reduction factor (VRF) (Equation (2)). When the retention rate is $100 \%, \mathrm{VRF}$ is equal to $\mathrm{CF}$.

$$
\begin{gathered}
\mathrm{CF}=\frac{C_{\text {conductivity-RO concentrate }}}{C_{\text {conductivity-RO feed }}} \\
\operatorname{VRF}=\frac{Q_{p}}{Q_{c}}+1
\end{gathered}
$$

where $C_{\text {conductivity-Ro feed }}$ and $C_{\text {conductivity-RO concentrate }}$ are the measured conductivity $\left(\mu \mathrm{S} \cdot \mathrm{cm}^{-1}\right)$ in RO feed and bulk RO concentrate, respectively. $Q_{c}$ and $Q_{p}$ are the flow rate $\left(\mathrm{L} \cdot \mathrm{h}^{-1}\right)$ of RO concentrate and RO permeate, respectively.

In this work, the RO process was operated at a cross-flow velocity of 0.18 $\mathrm{m} \cdot \mathrm{s}^{-1}$ and $22^{\circ} \mathrm{C} \pm 1^{\circ} \mathrm{C}$. The transmembrane pressure $(\Delta P)$ was around 7 bar. $\mathrm{CF}$ was set to around 3. The MBR permeate that was produced from the MBR was continuously fed to the RO process at an average flow rate of $16.8 \mathrm{~L} \cdot \mathrm{d}^{-1}$. RO concentrate $\left(6.0 \mathrm{~L} \cdot \mathrm{d}^{-1}\right)$ were collected in a tank and were continuously recycled to the MBR unit at a flow rate of $4.8 \mathrm{~L} \cdot \mathrm{d}^{-1}$, which represented one-fifth of MBR feed flow (RO concentrate + wastewater). To prevent inorganic scaling on the RO membrane surface, the solution $\mathrm{pH}$ of $\mathrm{MBR}$ permeate as $\mathrm{RO}$ feed was adjusted to $\sim 6$ by using $1 \mathrm{~mol} \cdot \mathrm{L}^{-1} \mathrm{HCl}$. At the end of the filtration period, the recirculation loop was deconcentrated with distilled water, aiming to check for membrane fouling reversibility.

During the filtration of MBR permeate, the permeate flux $(\zeta)$ of the RO membrane and the permeability $\left(L_{p}\right.$ at $\left.22^{\circ} \mathrm{C}\right)$ were calculated using the following equations:

$$
\begin{gathered}
J=\frac{Q_{p}}{A_{m}} \\
L_{p}=\frac{J}{\Delta P-\Delta \pi} \\
\Delta P=\frac{P_{f}+P_{c}}{2}-P_{p}
\end{gathered}
$$

where $J$ represents the permeate flux of the RO membrane $\left(\mathrm{L} \cdot \mathrm{h}^{-1} \cdot \mathrm{m}^{-2}\right) . A_{m}$ is the specific surface area of the RO membrane $\left(\mathrm{m}^{2}\right) . L_{p}$ represents the permeability of the $\mathrm{RO}$ membrane at $22^{\circ} \mathrm{C}\left(\mathrm{L} \cdot \mathrm{h}^{-1} \cdot \mathrm{m}^{-2} \cdot \mathrm{bar}^{-1}\right) . \Delta \pi$ represents the osmotic pressure gradient across RO membrane (bar). $P_{f}, P_{c}$ and $P_{p}$ are the pressure on the side of RO feed, RO concentrate and RO permeate, respectively (bar). 
The observed retention $\left(R_{o b s}\right)$ for global parameters such as organics and ions gave direct information on the performance of the RO membrane, and was calculated by Equation (6).

$$
R_{\text {obs }}(\%)=\left(1-\frac{C_{p}}{C_{c}}\right) \times 100
$$

where $C_{p}$ and $C_{c}$ refer to the concentration of a selected parameter (NPOC, ionic salts, etc.) in RO permeate and in the bulk RO concentrate, respectively.

\subsection{Calculation of Saturation Index}

Scaling formation was expected to be a function of mineral salt over-saturation at the membrane surface. The saturation index (SI) value is commonly used to assess the supersaturation degree of salts such as $\mathrm{AaBb}$ in the solution, and can be defined as [21]:

$$
\begin{aligned}
& \mathrm{SI}=\log \left(\frac{\mathrm{IAP}}{K_{s p}}\right) \\
& \mathrm{IAP}=[A]^{a}[B]^{b}
\end{aligned}
$$

where IAP is the ionic activity product. $K_{s p}$ is the solubility product constant of the related salts. A positive SI value shows that the compound is over-saturated, which is related to a risk of scaling, whereas an SI value below zero corresponds to under-saturation of the solution [21]. PHREEQC software [23] was used to calculate the SI values of different salts in the non-ideal aqueous solution.

\subsection{Analytical Methods}

Conductivity was recorded by an LF538 conductivity meter (WTW, Germany). COD was detected by a digestion reactor (HACH Co., USA) and a direct reading spectrometer (DR/2000, HACH Co., USA). The determination of NPOC and DIC was performed on a TOC analyser (VCSH-TOC, Schimadzu, Japan) after samples passed through a $0.45 \mu \mathrm{m}$ PES filter. Ultraviolet absorbance (UVA) of solution samples filtered with a $0.45 \mu \mathrm{m}$ PES filter was measured using a UV/Visible V-530 spectrophotometer (Shimadzu, Japan) at a given wavelength (254 nm and $280 \mathrm{~nm}$ ) with a quartz cell having a path length of $1 \mathrm{~cm}$. Concentrations of anions and cations were determined with an ionic chromatography (IC) system (IC 25 and ICS-2000, Dionex, USA). Proteins and polysaccharides were quantified by the bicinchoninic acid assay method [24] and the Anthrone method [25], respectively. HPLC-SEC analysis was carried out in an Akta Purifier with a fluorescence detector (Varian, USA) [26].

\section{Results and Discussion}

\subsection{Influence of RO Concentrate Recycling on RO Retention Capacity for Organic Matters}

Dissolved organic carbon (NPOC) and proteins were considered as indicators to 
evaluate $\mathrm{RO}$ performance in terms of $\mathrm{RO}$ retention capacity for organic matters in the MBR-RO system with $\mathrm{RO}$ concentrate recycling. The observed retention for such parameters was calculated based on their concentration measured in the bulk RO concentrate and RO permeate, as shown in Equation (6).

Figure 2 displays the concentration of organic matters in terms of NPOC in the three flows, including RO feed, RO permeate and RO concentrate, before and during $\mathrm{RO}$ concentrate recirculation. The recirculation of $\mathrm{RO}$ concentrate induced an increase up to a factor of 2.2 in the concentration of NPOC in RO feed after two weeks. There were two reasons for this increase of organic matters in RO feed: one was the recirculation of poorly biodegradable organics with small molecular weight (MW) from RO concentrate to MBR influents; and the other was that the continuous addition of salts into the MBR may decrease the microbial activity for the degradation of low MW organics in the MBR or increase SMPs' release. Regarding RO concentrate, after only 2 days of recycling, the concentration of NPOC rose rapidly from $20.4 \pm 0.4 \mathrm{mg} \cdot \mathrm{L}^{-1}$ before recycling to $25.6 \pm 0.5 \mathrm{mg} \cdot \mathrm{L}^{-1}$ and then maintained a relatively constant level over the following 7 days. After 9 days of recycling, the concentration of NPOC increased sharply, and finally reached $35.0 \pm 0.6 \mathrm{mg} \cdot \mathrm{L}^{-1}$ in the next 5 days. The rapid increase of NPOC in RO concentrate mainly resulted from the increase in organic matters in $\mathrm{RO}$ feed and the excellent rejection (>98\%) by the RO membrane. Despite RO concentrate recirculation, the concentration of NPOC in RO permeate remained constant, at a value below $0.57 \pm 0.01 \mathrm{mg} \cdot \mathrm{L}^{-1}$. The concentration profile of chemical oxygen demand (COD) was similar to the NPOC curve, as presented in Figure S1 (see Supplementary information).

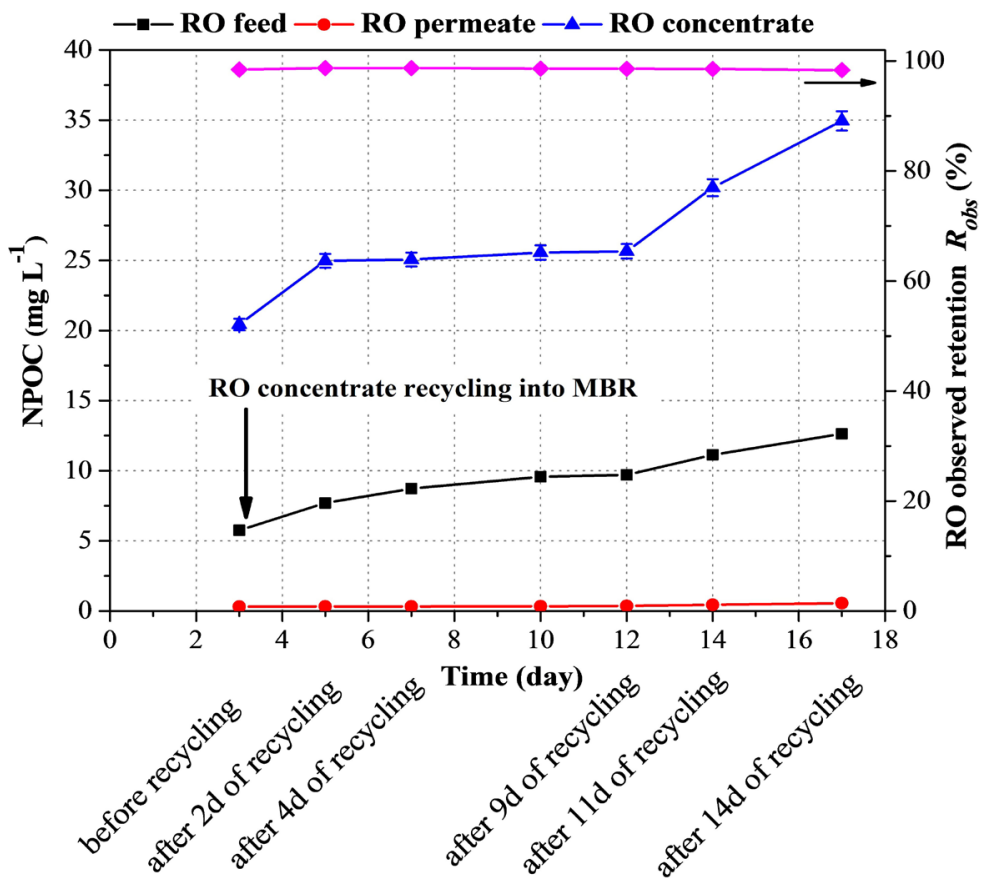

Figure 2. Variation of NPOC in RO flows with the recirculation of RO concentrate. Cross-flow velocity: $0.18 \mathrm{~m} \cdot \mathrm{s}^{-1} . \Delta P: \sim 7$ bar. CF: 3 . 
To better understand the variation of organic matters during $\mathrm{RO}$ concentrate recycling, the molecular size distribution of protein-like substances in RO flows was recorded by HPLC-SEC-fluorescence, as depicted in Figure 3. Before RO concentrate recirculation, HPLC-SEC analysis of both RO feed and RO concentrate showed two distinct peaks, i.e., a high peak for $10-100 \mathrm{kDa}$ protein-like components and a small peak for protein-like molecules smaller than $10 \mathrm{kDa}$, respectively (Figure 3(a)). In contrast, a negligible response to fluorescence in RO permeate indicated that these two groups of protein-like substances were retained totally on the RO membrane surface. After 13 days of RO retentate addition, the concentration of both $<10 \mathrm{kDa}$ and $10-100 \mathrm{kDa}$ protein-like substances increased significantly, as indicated in Figure 3(b). For example, for protein-like molecules with $10-100 \mathrm{kDa}$, an increase of $80 \%$ in peak height for RO feed and of $40 \%$ for RO concentrate was found.

After that, the concentration of proteins in RO solutions was quantitified, as shown in Figure 4. It appeared that only 2 days after RO concentrate recycling
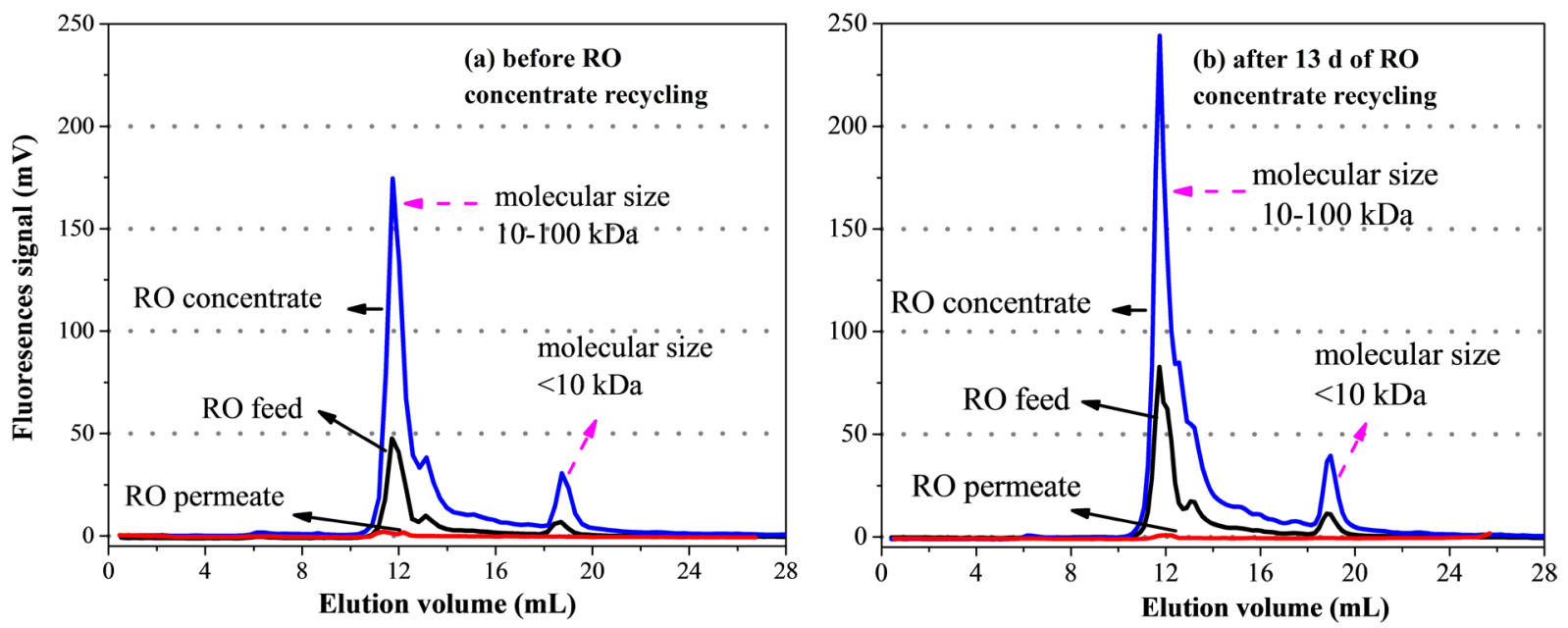

Figure 3. HPLC-SEC analysis of RO flows before and after RO concentrate recirculation to MBR unit.

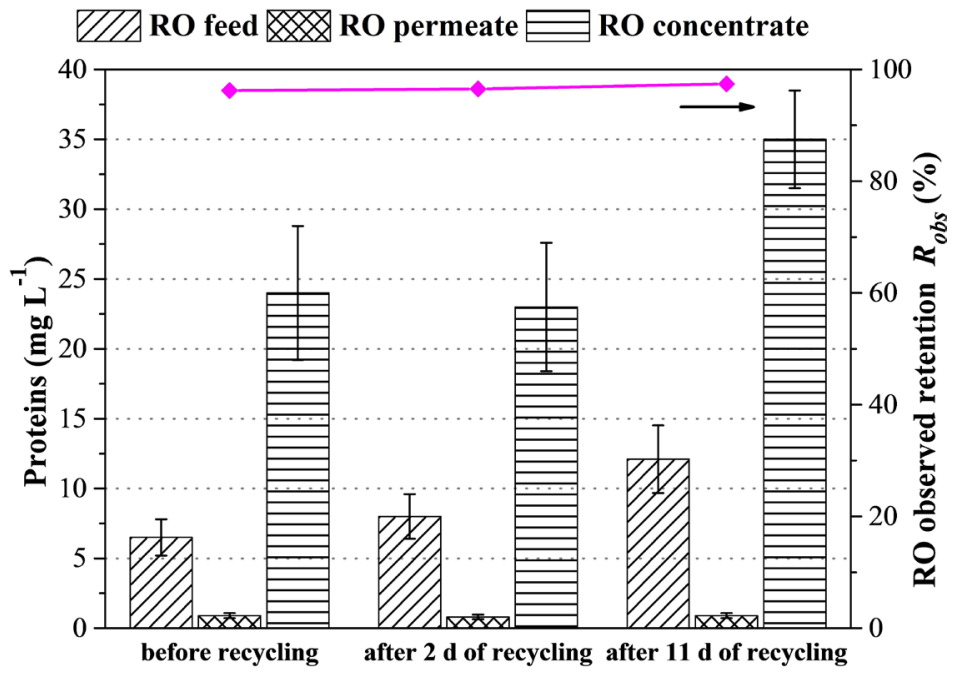

Figure 4. Concentration of proteins in $\mathrm{RO}$ flows before and after $\mathrm{RO}$ concentrate recirculation. 
caused an increase by a factor of 1.2 for proteins in MBR permeate. After 11 days of RO concentrate addition, in RO feed, the concentration of proteins reached $12.1 \pm 2.4 \mathrm{mg} \cdot \mathrm{L}^{-1}$. With respect to $\mathrm{RO}$ concentrate, before $\mathrm{RO}$ concentrate recycling, the concentration of proteins was around $24.0 \pm 4.8 \mathrm{mg} \cdot \mathrm{L}^{-1}$. After 11 days of RO retentate addition, the concentration of proteins was 1.5 times higher compared to before RO concentrate recycling. Figure S2 (see Supplementary Information) showed that the concentration of polysaccharides increased during $\mathrm{RO}$ concentrate recycling to MBR.

These results appeared to demonstrate that the quality of RO permeate in terms of organic matters was not significantly affected during RO concentrate recycling.

\subsection{Influence of RO Concentrate Recycling on RO Retention Capacity for Salts}

One of the important constituents responsible for $\mathrm{RO}$ membrane fouling was inorganic salts present in $\mathrm{RO}$ feed. Thus, after $\mathrm{RO}$ retentate recycling to the $\mathrm{MBR}$, the concentration of inorganic salts in RO system was also addressed. Figure 5 plots the conductivity variation in RO flows versus the operation time. RO concentrate injection into the MBR unit elevated significantly the conductivity in MBR permeate and in RO concentrate until Day 7 (4 days after start of RO concentrate recycling). After that, the curve showed a plateau for the next 10 days. The conductivity of RO concentrate was approximately 3 -fold higher than that of MBR permeate, which revealed that the RO filtration was carried out with a nearly constant CF of 3 in terms of conductivity. In contrast, variation in

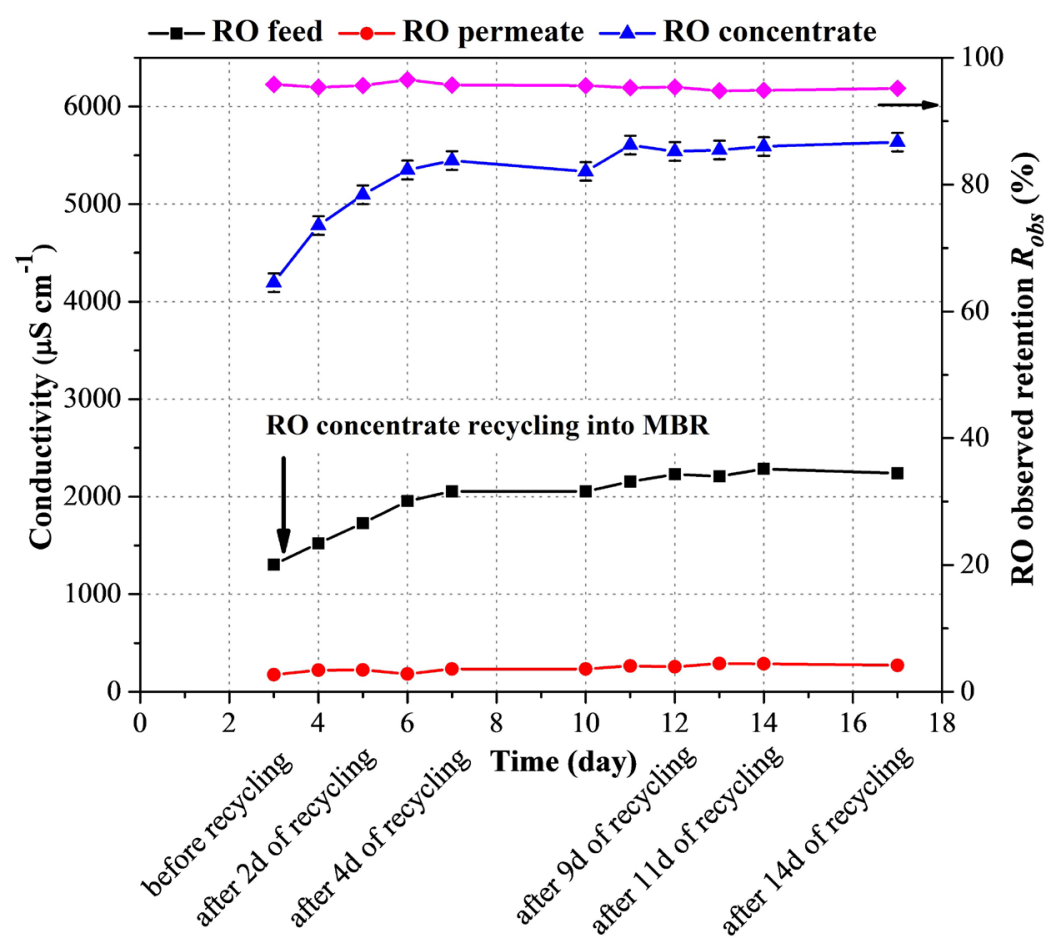

Figure 5. Variation of conductivity in RO flows as a function of operation time. 
the conductivity of RO permeate was less significant, with values ranging only between $176 \pm 4 \mu \mathrm{S} \cdot \mathrm{cm}^{-1}$ and $290 \pm 6 \mu \mathrm{S} \cdot \mathrm{cm}^{-1}$. Throughout the experiment, the observed retention of conductivity was around $95 \%$.

Table 2 displays the retention capacities of the RO membrane for anions and cations before and during RO concentrate recirculation. Firstly, as expected, before $\mathrm{RO}$ concentrate recycling, the $\mathrm{RO}$ membrane presented the retention rate higher than $86 \%$ for every ion not including $\mathrm{P}^{-} \mathrm{PO}_{4}^{3-}$. Hence, the continuous addition of RO concentrate did not influence the retention capacities of the RO membrane for most of ions. The abnormal trend of the retention of the RO membrane for $\mathrm{P}^{-} \mathrm{PO}_{4}^{3-}$ is possibly related to the variation in concentration of $\mathrm{P}_{-} \mathrm{PO}_{4}^{3-}$ in the bulk RO concentrate and the changed $\mathrm{pH}$ of RO concentrate. Pinto et al. (2011) pointed out that, when solution $\mathrm{pH}$ increased more basic values, calcium phosphate becomes increasingly insoluble [27]. As illustrated in Table 2, it was also noticed similar retention capacities of the RO membrane for all monovalent or divalent ions, suggesting that other mechanisms were also responsible for the rejection of the RO membrane for the tested ions, in addition to the hydrated ion sizes and the charge effect.

Figure 6 shows the variation of ionic concentration before and during RO concentrate recirculation. Since the MF membrane in MBR was not effective to reject inorganic ions, the continuous recirculation of $\mathrm{RO}$ concentrate with a high load of ionic salts led to a significant rise in the concentration of ionic salts in both RO feed and RO concentrate. After 11 days of RO retentate addition, the ion concentration in $\mathrm{RO}$ feed was 4.0 times larger for $\mathrm{Cl}^{-}, 1.4$ times larger for $\mathrm{N}-\mathrm{NO}_{3}^{-}, 1.9$ times larger for $\mathrm{SO}_{4}^{2-}, 1.7$ times larger for $\mathrm{P}^{-} \mathrm{PO}_{4}^{3-}, 2.3$ times larger for $\mathrm{Na}^{+}, 2.0$ times larger for $\mathrm{K}^{+}, 2.1$ times larger for $\mathrm{Mg}^{2+}$, and 1.7 times larger for $\mathrm{Ca}^{2+}$ than that obtained before RO concentrate recycling. With respect to RO concentrate, as compared to the initial results (without RO concentrate recycling), 11

Table 2. RO membrane retention capacity for anions and cations.

\begin{tabular}{ccccc}
\hline $\mathrm{R}_{\text {obs }}(\%)^{\mathrm{a}}$ & $\begin{array}{c}\text { Hydrated radius } \\
(\mathbf{n m})^{\mathrm{b}}\end{array}$ & before recycling & $\begin{array}{c}\text { after 4d of } \\
\text { recycling }\end{array}$ & $\begin{array}{c}\text { after 11d of } \\
\text { recycling }\end{array}$ \\
\hline $\mathrm{pH}$ of $\mathrm{RO}$ concentrate & - & 7.40 & 7.14 & 6.90 \\
$\mathrm{Cl}^{-}$ & 0.332 & 96 & 95 & 95 \\
$\mathrm{~N}^{-\mathrm{NO}_{3}^{-}}$ & 0.335 & 86 & 89 & 88 \\
$\mathrm{HCO}_{3}^{-}$ & $-\mathrm{c}$ & 95 & 97 & 97 \\
$\mathrm{SO}_{4}^{2-}$ & 0.379 & 98 & 98 & 99 \\
$\mathrm{P}^{-\mathrm{PO}_{4}^{3-}}$ & $-\mathrm{c}$ & 77 & 90 & 93 \\
$\mathrm{Na}^{+}$ & 0.358 & 95 & 95 & 93 \\
$\mathrm{~K}^{+}$ & 0.331 & 97 & 95 & 93 \\
$\mathrm{Mg}^{2+}$ & 0.428 & 97 & 98 & 98 \\
$\mathrm{Ca}^{2+}$ & 0.412 & 96 & 97 & 98 \\
\hline
\end{tabular}

${ }^{a} R_{o b s}$ is calculated by Equation (6). ${ }^{b}$ values from [28]. ${ }^{c}$ not found in the literature. 

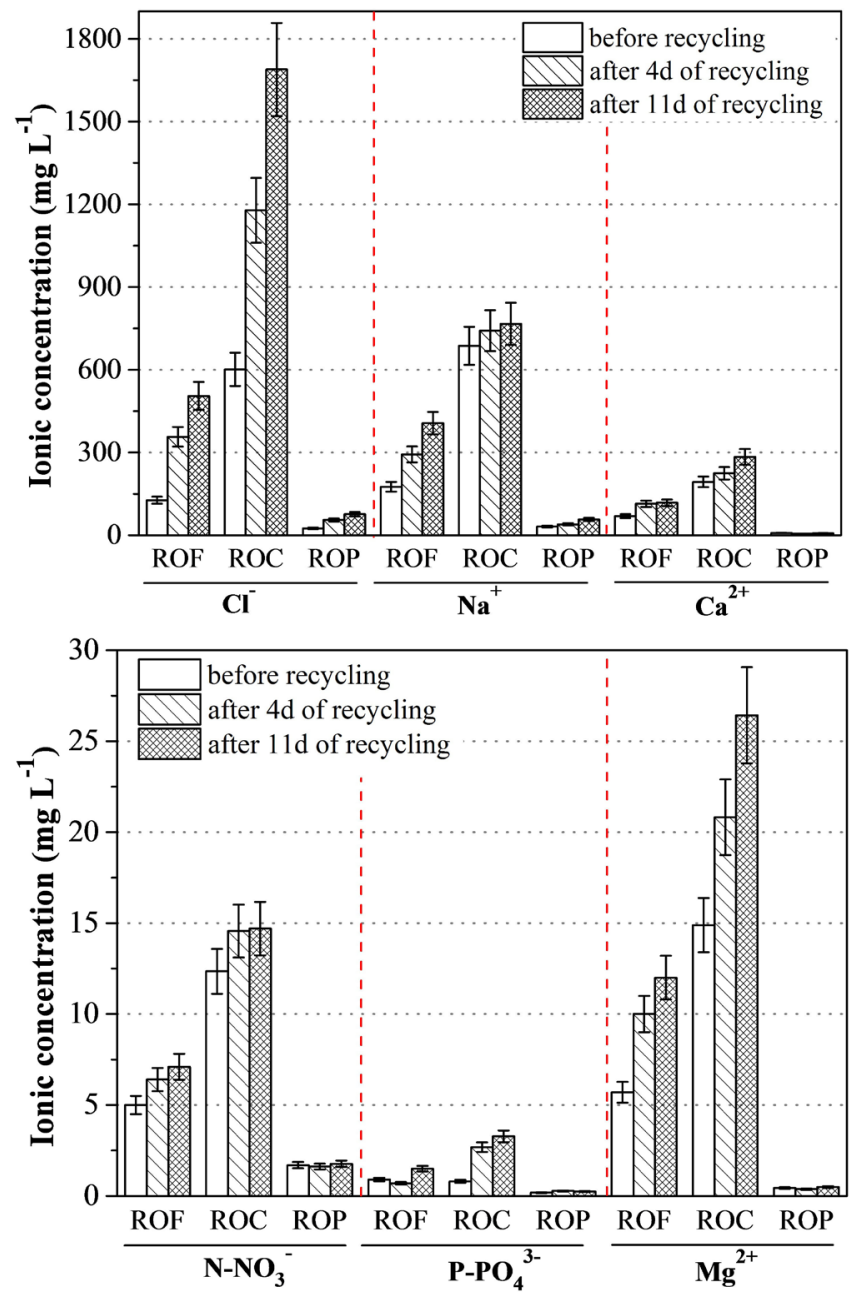

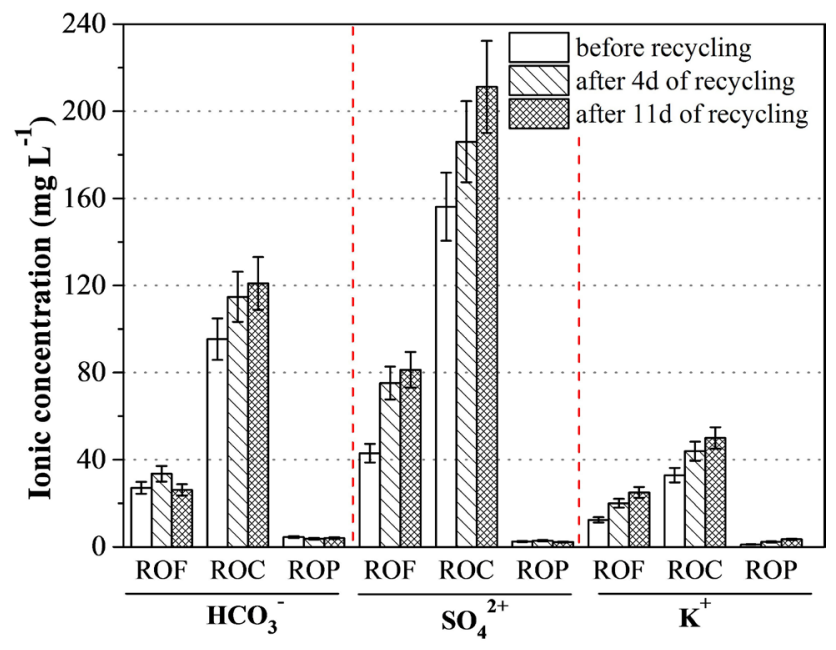

ROF: RO feed ROC: RO concentrate ROP: RO permeate

Figure 6. Effect of RO concentrate recycling on the concentration of ionic salts in RO flows.

days of RO concentrate recirculation also increased the concentration of these ions, 2.9 times for $\mathrm{Cl}^{-}, 1.2$ times for $\mathrm{N}-\mathrm{NO}_{3}^{-}, 1.4$ times for $\mathrm{SO}_{4}^{2-}, 4.1$ times for $\mathrm{P}_{-} \mathrm{PO}_{4}^{3-}, 1.1$ times for $\mathrm{Na}^{+}, 1.5$ times for $\mathrm{K}^{+}, 1.8$ times for $\mathrm{Mg}^{2+}$, and 1.5 times for $\mathrm{Ca}^{2+}$, respectively. The different increased level of $\mathrm{Cl}^{-}$in $\mathrm{RO}$ feed (4.0 times higher) and RO concentrate (2.9 times higher) was associated with the addition of $\mathrm{HCl}$ for controlling $\mathrm{RO}$ membrane scaling.

To sum up, the continuous addition of RO concentrate did not influence remarkably the global performance of the RO system in terms of RO permeate quality or the retention capacities of the most common monitoring parameters. The RO permeate produced without and with RO concentrate recirculation could meet the standard for reclaimed water reuse in several industrial processes or for indirect potable reuse [29].

\subsection{RO Membrane Fouling Propensity}

As discussed above, the recirculation of RO concentrate to the MBR resulted in a significant increase in the concentration of inorganic or organic substances in MBR permeate. Consequently, the continuous accumulation of solutes in RO 
concentrate possibly affected RO membrane fouling potential. In this section, RO membrane fouling was examined through the variation of the RO permeate flux versus operating time, osmotic pressure model and saturation index (SI).

\subsubsection{Membrane Fouling in Terms of RO Permeate Flux Decline}

Figure 7 shows the RO permeate flux behaviour before and during RO concentrate addition to the MBR. Three different stages were identified in Figure 7: Stage 1 (0 - Hour 5, CF increase, no RO concentrate recycling), Stage 2 (Hour 5 Day 3, CF kept constant at 3, no RO concentrate recycling), and Stage 3 (Day 3 Day 17, CF kept constant at 3, RO concentrate recycling). In Stage 1, a rapid decline in permeate flux was observed, with a reduction of approximately $30 \%$ of the initial permeate flux when $\mathrm{CF}$ reached 3. This remarkable loss in RO permeate flux could be linked to a rapid accumulation of solutes (inorganic ions and organic matters) on the RO membrane surface with CF increase. In the following 3 days (Stage 2), RO permeate flux remained almost constant. Once RO concentrate was added into the MBR from Day 3 (Stage 3), RO permeate flux started to decrease slowly over the next 14 days, and an additional $19 \%$ reduction in RO permeate flux was noted, from $8.9 \mathrm{~L} \cdot \mathrm{h}^{-1} \cdot \mathrm{m}^{-2}$ to $6.5 \mathrm{~L} \cdot \mathrm{h}^{-1} \cdot \mathrm{m}^{-2}$.

At the end of the experiment, the recirculation loop was deconcentrated with distilled water as RO feed. After 3.5 hours' deconcentration of the recirculation loop with distilled water at the same cross-flow velocity of $0.18 \mathrm{~m} \cdot \mathrm{s}^{-1}$, around $35 \%$ of the initial RO permeate flux could be recovered, indicating that the accumulation of some solutes was removable. On the other hand, the incomplete recovery of the flux (around 16\% of initial RO permeate flux) may be associated with a colloidal cake layer or adsorption of organic matters on the RO membrane surface.

To comprehensively evaluate the impact of RO retentate recycling on RO

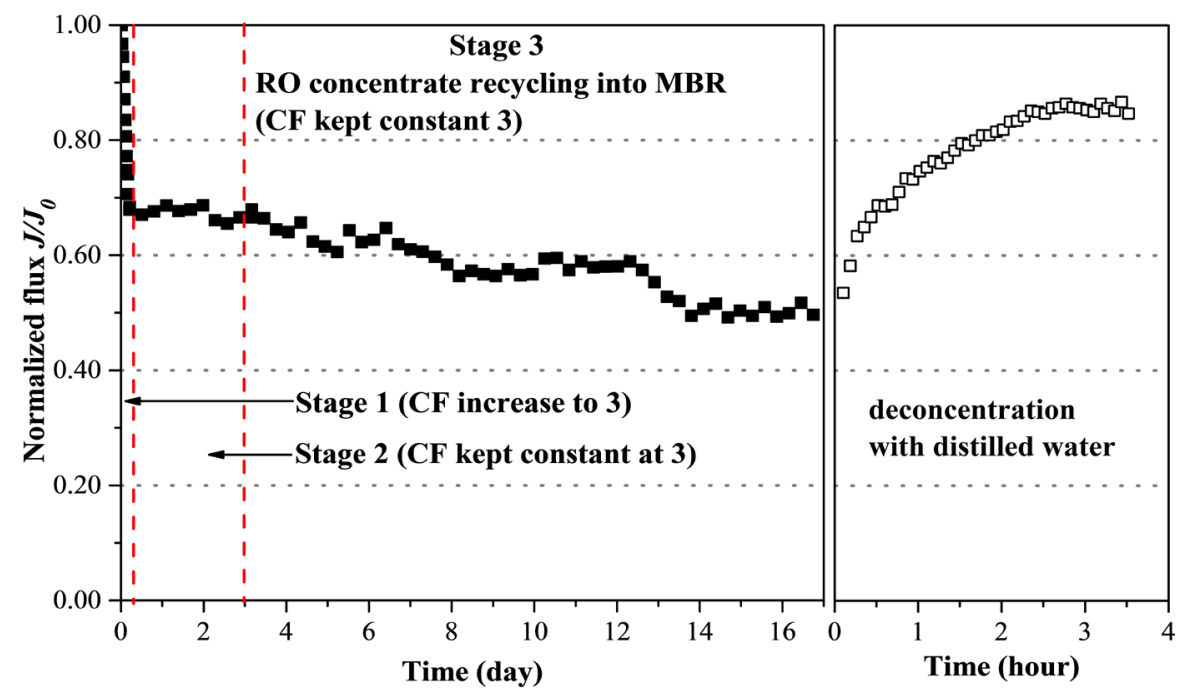

Figure 7. RO permeate flux behaviour throughout the operating time. Cross-flow velocity: $0.18 \mathrm{~m} \cdot \mathrm{s}^{-1}$. initial permeate flux: $12.5 \mathrm{~L} \cdot \mathrm{h}^{-1} \cdot \mathrm{m}^{-2} . \Delta P: \sim 7$ bar. operating temperature: $22^{\circ} \mathrm{C} \pm 1^{\circ} \mathrm{C}$. uncertainty of $J / J_{0}: \pm 0.08$. 
fouling behaviour, deeper analysis was developed below regarding the role of inorganic salts and organics in the reduction of RO permeate flux.

\subsubsection{Impact of Osmotic Pressure Gradient of Salts on Ro Permeate Flux Decline}

The continuous recirculation of $\mathrm{RO}$ concentrate caused a high ionic concentration at the RO membrane surface, so it could be possible that the increased osmotic pressure of the ions retained at the membrane surface affected the RO permeate flux. To address this point, the osmotic pressure model (Equation (9)) was used to study the effect of the increased osmotic pressure of the ions retained at the membrane surface on the RO permeate flux through the $\mathrm{RO}$ membrane.

$$
J_{\text {model }}=L_{p 0}(\Delta P-\Delta \pi)
$$

where $J_{\text {model }}$ refers to the RO permeate flux that is calculated with the osmotic pressure model $\left(\mathrm{L} \cdot \mathrm{h}^{-1} \cdot \mathrm{m}^{-2}\right) . L_{p 0}$ is the permeability of the RO membrane with distilled water $\left(1.9 \mathrm{~L} \cdot \mathrm{h}^{-1} \cdot \mathrm{m}^{-2} \cdot \mathrm{bar}^{-1}\right) . \Delta \pi$ is the osmotic pressure difference (bar) of ionic salts between the membrane surface and the RO permeate side, which can be calculated with the Van't Hoff equation [30]:

$$
\Delta \pi=\pi_{m}-\pi_{p}=\sum C_{m, i} Z_{i} R T-\sum C_{p, i} Z_{i} R T
$$

where $\pi_{m}$ and $\pi_{p}$ are the osmotic pressure of ions at the RO membrane surface and in RO permeate side ( $\mathrm{Pa})$, respectively. The unit of both $\pi_{m}$ and $\pi_{p}$ is converted to bar $\left(1 \mathrm{bar}=10^{5} \mathrm{~Pa}\right) . z_{i}$ is the valency of ion $i . T$ is the absolute temperature $(K) . R$ is the ideal gas constant, $8.3145 \mathrm{~J} \cdot \mathrm{mol}^{-1} \cdot \mathrm{K}^{-1}$ or $8.3145 \mathrm{~m}^{3}$ $\mathrm{Pa} \cdot \mathrm{mol}^{-1} \cdot \mathrm{K}^{-1} \cdot C_{p, i}$ is the concentration of ion $i$ in $\mathrm{RO}$ permeate $\left(\mathrm{mol} \cdot \mathrm{L}^{-1}\right)$, which can be obtained from the experimental data (see Figure 6). $C_{m, i}$ represents the concentration $\left(\mathrm{mol} \cdot \mathrm{L}^{-1}\right)$ of ion $i$ at the RO membrane surface, which cannot be measured directly but can be estimated by Equation (11).

$$
\ln \frac{C_{m, i}-C_{p, i}}{C_{c, i}-C_{p, i}}=\frac{J_{\text {exp }}}{k_{i}}
$$

where $C_{c, i}$ represents the concentration of ion $i$ in the bulk RO concentrate $\left(\mathrm{mol} \cdot \mathrm{L}^{-1}\right.$ ), the value of which is found from the experiment (see Figure 6). $J_{\exp }$ is the RO permeate flux from experiments (see Figure 7). $k_{i}$ refers to the mass transfer coefficient of ion $i\left(\mathrm{~m} \cdot \mathrm{s}^{-1}\right)$, which can be estimated based on the equations provided by Hoek et al. (2008) (see Supplementary Information).

Based on the $k_{i}$ value (Table S3, Supplementary Information) and the ionic concentration measured in both the RO permeate $\left(C_{p}\right)$ and bulk RO concentrate $\left(C_{c}\right)$, the concentration of each ion at the RO membrane surface $\left(C_{m}\right)$ was calculated before and during RO concentrate addition, as shown in Table S4 (see Supplementary Information). From Equation (9), the flux decline due to osmotic pressure effect could be obtained.

Figure 8 shows the osmotic pressure gradient of inorganic salts and the RO permeate flux decline from both the test $\left(J_{\text {exp }}\right)$ and the model $\left(J_{\text {model }}\right)$. During the 


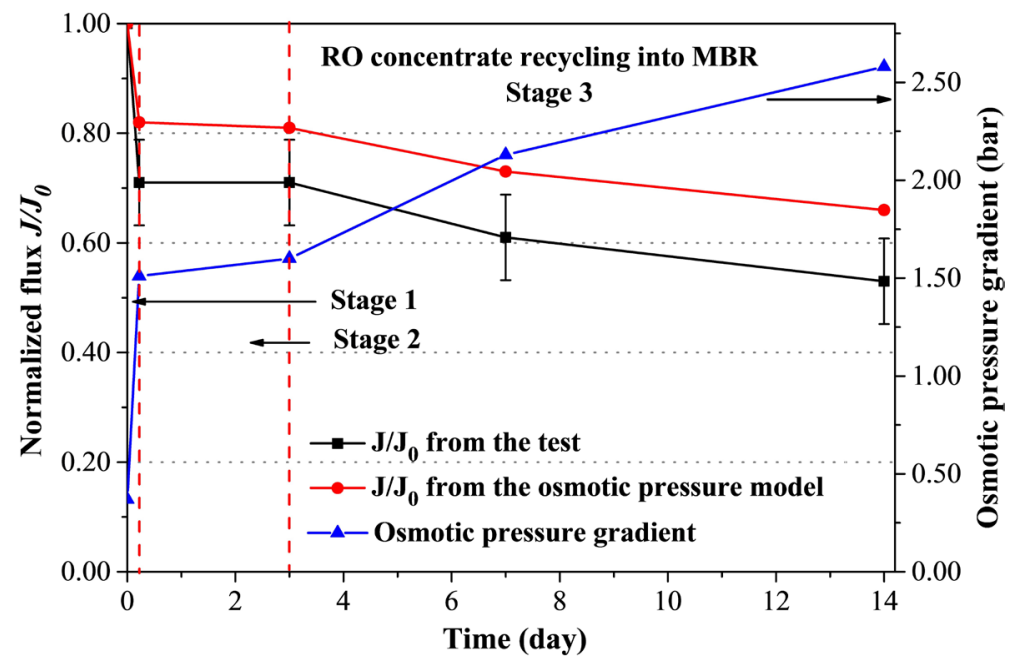

Figure 8. Variation of the osmotic pressure gradient of retained ions and RO permeate flux as a function of operation time. Cross-flow velocity: $0.18 \mathrm{~m} \cdot \mathrm{s}^{-1} . \Delta P: \sim 7$ bar. initial permeate flux for both the test and the model: $12.5 \mathrm{~L} \cdot \mathrm{h}^{-1} \cdot \mathrm{m}^{-2}$.

period of CF increase (Stage 1), the osmotic pressure gradient of inorganic salts increased, from the initial 0.4 bar $(\mathrm{CF}=1)$ to 1.5 bar when $\mathrm{CF}$ reached 3 . The increase of osmotic pressure gradient led to a reduction of $18 \%$ in permeate flux from the model, which was lower than the reduction in permeate flux found in the experiment, with a value around $30 \%$, revealing that other fouling behaviour, such as the precipitation of salts, adsorption or a cake layer caused by smaller colloids at the RO membrane surface, took place in this stage. In the following 3 days (Stage 2), the osmotic pressure gradient and RO permeate flux stayed almost constant. However, when RO concentrate was added continuously to the MBR from Day 3 (Stage 3), the osmotic pressure gradient of inorganic salts increased gradually, reaching 2.6 bar after $11 \mathrm{~d}$ of RO concentrate recycling (Day 14). Correspondingly, the RO permeate flux from the model decreased continuously. In addition, comparing the behaviour of flux in the test and the model (Stage 3), a similar slope as a function of operating time revealed that the increased osmotic pressure caused by RO concentrate recirculation was a dominant factor causing the additional $19 \%$ reduction in RO permeated flux during this stage.

In conclusion, except Stage 1 at the beginning, the RO permeate flux decrease was due to the increased osmotic pressure of retained ions. At the first stage of the operation, adsorption phenomena or colloidal cake layer could happen, which represented $15 \%$ of the RO permeate flux decline. This point was confirmed by the reversibility of the fouling by the deconcentration of the recirculation loop with distilled water.

\subsubsection{Scaling Potential Analysis Based on Saturation Index Model}

To confirm a minor effect of inorganic scaling (the precipitation of ionic salts) on the $\mathrm{RO}$ permeate flux decline, the most common scalants, hydroxyapatite $\left(\mathrm{Ca}_{5}\left(\mathrm{PO}_{4}\right)_{3} \mathrm{OH}\right)$, calcite $\left(\mathrm{CaCO}_{3}\right)$ and gypsum $\left(\mathrm{CaSO}_{4} \cdot 2 \mathrm{H}_{2} \mathrm{O}\right)$, were used to predict RO membrane scaling (Jiang et al., 2017). Detailed infor- 
mation on calculation of saturation index of these salts is described in the Supplementary Inforamtion. Thus, the ionic concentration in RO concentrate was used to estimate the SI value with PHREEQC model. Table 3 summarizes the SI values of three scalants in the bulk RO concentrate before and during RO concentrate recirculation. Before or during RO concentrate recirculation, SI values of alkaline calcite and non-alkaline gypsum were lower than zero, indicating that the corresponding ionic salts were undersaturated. Their lower SI values can be explained by their high $k_{\mathrm{sp}}: 2.80 \times 10^{-9}$ for calcite and $4.93 \times 10^{-5}$ for gypsum. Moreover, with $\mathrm{RO}$ concentrate recirculation, a decreasing trend of the SI values for calcite and hydroxyapatite could be explained by the different $\mathrm{pH}$ values of $\mathrm{RO}$ concentrate at the different operating time. Compared to calcite and gypsum, the SI values of hydroxyapatite, with a relatively low $k_{s p}$ of $2.34 \times 10^{-59}$, were above 0 during the entire process, which meant that non-alkaline hydroxyapatite occurred on the $\mathrm{RO}$ membrane surface. Nonetheless, $\mathrm{P}^{-\mathrm{PO}_{4}^{3-}}$ concentration in MBR permeate was low, with a value of around $0.90 \mathrm{mg} \cdot \mathrm{L}^{-1}$. Thus, inorganic precipitation may have become less pronounced for RO membrane fouling potential in this work.

\section{Conclusions}

The main objective was to elucidate the impacts of RO concentrate recycling on the performance of the RO process for treating MBR permeate, in terms of the retention efficiency of common parameters by the RO membrane and the fouling propensity of this membrane. In this work, $\mathrm{RO}$ concentrate, produced by the RO process at a fixed CF around 3, was added continuously to the MBR, representing $20 \%$ of the total MBR inflow. The results obtained suggested that, regardless of RO retentate recycling to the MBR unit, the RO membrane in this integrated system still maintained a relatively stable and effective retention capacity for the global water quality parameters, for instance, $>98 \%$ for NPOC and $>95 \%$ for conductivity.

Since the recirculation of $\mathrm{RO}$ concentrate changed the concentration of inorganic and organic species in MBR permeate (as RO feed) and RO concentrate, the fouling propensity of the $\mathrm{RO}$ membrane was enhanced, which was mainly

Table 3. Saturation index of three common scalants before and after RO concentrate recirculation

\begin{tabular}{cccccc}
\hline & & & \multicolumn{3}{c}{ CF around 3 } \\
\cline { 5 - 6 } & & $\mathbf{k}_{\text {sp }}{ }^{2}$ & $\begin{array}{c}\text { Before } \\
\text { recycling }\end{array}$ & $\begin{array}{c}\text { after 4 d of } \\
\text { recycling }\end{array}$ & $\begin{array}{c}\text { after 11 d of } \\
\text { recycling }\end{array}$ \\
\cline { 5 - 7 } pH of RO concentrate & - & - & 7.4 & 7.1 & 6.9 \\
Calcite & $\mathrm{CaCO}_{3}$ & $2.80 \times 10^{-9}$ & -0.06 & -0.21 & -0.38 \\
Gypsum & $\mathrm{CaSO}_{4} \cdot 2 \mathrm{H}_{2} \mathrm{O}$ & $4.93 \times 10^{-5}$ & -1.29 & -1.21 & -1.10 \\
Hydroxyapatite & $\mathrm{Ca}_{5}\left(\mathrm{PO}_{4}\right)_{3} \mathrm{OH}$ & $2.34 \times 10^{-59}$ & 6.76 & 4.53 & 3.93 \\
\hline
\end{tabular}

afrom [31]. 
due to an increase in the osmotic pressure of retained ions at the RO membrane surface. In addition, over the entire process, a reduction of approximately $15 \%$ of the initial RO permeate flux was linked to adsorption or a colloidal fouling layer at the RO membrane surface.

Overall, the integrated MBR-RO system with RO concentrate recycling could minimize the quantity of the $\mathrm{RO}$ concentrate waste stream. In view of the RO permeate flux decline mainly due to the increased osmotic pressure of retained ions, the amount of inorganic ions brought to the MBR by RO concentrate recirculation should be reduced by using several technologies (such as capacitive deionisation process) in future works.

\section{Conflicts of Interest}

The authors declare no conflicts of interest regarding the publication of this paper.

\section{References}

[1] Cartagena, P., El Kaddouri, M., Cases, V., Trapote, A. and Prats, D. (2013) Reduction of Emerging Micropollutants, Organic Matter, Nutrients and Salinity from Real Wastewater by Combined MBR-NF/RO Treatment. Separation and Purification Technology, 110, 132-143. https://doi.org/10.1016/j.seppur.2013.03.024

[2] Dolar, D., Gros, M., Rodriguez-Mozaz, S., Moreno, J., Comas, J., Rodriguez-Roda, I. and Barceló, D. (2012) Removal of Emerging Contaminants from Municipal Wastewater with an Integrated Membrane System, MBR-RO. Journal of Hazardous Materials, 239-240, 64-69. https://doi.org/10.1016/j.jhazmat.2012.03.029

[3] Jacob, M., Guigui, C., Cabassud, C., Darras, H., Lavison, G. and Moulin, L. (2010) Performances of RO and NF Processes for Wastewater Reuse: Tertiary Treatment after a Conventional Activated Sludge or a Membrane Bioreactor. Desalination, 250, 833-839. https://doi.org/10.1016/j.desal.2008.11.052

[4] Sahar, E., David, I., Gelman, Y., Chikurel, H., Aharoni, A., Messalem, R. and Brenner, A. (2011) The Use of RO to Remove Emerging Micropollutants Following CAS/UF or MBR Treatment of Municipal Wastewater. Desalination, 273, 142-147. https://doi.org/10.1016/j.desal.2010.11.004

[5] Jiang, S., Li, Y. and Ladewig, B.P. (2017) A Review of Reverse Osmosis Membrane Fouling and Control Strategies. Science of the Total Environment, 595, 567-583. https://doi.org/10.1016/j.scitotenv.2017.03.235

[6] Lee, S., Ang, W.S. and Elimelech, M. (2006) Fouling of Reverse Osmosis Membranes by Hydrophilic Organic Matter: Implications for Water Reuse. Desalination, 187, 313-321. https://doi.org/10.1016/j.desal.2005.04.090

[7] Luo, H., Li, H., Lu, Y., Liu, G. and Zhang, R. (2017) Treatment of Reverse Osmosis Concentrate Using Microbial Electrolysis Desalination and Chemical Production Cell. Desalination, 408, 52-59. https://doi.org/10.1016/j.desal.2017.01.003

[8] Moreno, J., Monclús, H., Stefani, M., Cortada, E., Aumatell, J., Adroer, N., De Lamo-Castellví, S. and Comas, J. (2013) Characterisation of RO Fouling in an Integrated MBR/RO System for Wastewater Reuse. Water Science and Technology, 67, 780-788. https://doi.org/10.2166/wst.2012.619

[9] Arola, K., Kallioinen, M., Reinikainen, S.-P., Hatakka, H. and Mänttäri, M. (2017) 
Advanced Treatment of Membrane Concentrate with Pulsed Corona Discharge. Separation and Purification Technology, 198, 121-127. https://doi.org/10.1016/j.seppur.2017.07.011

[10] Bagastyo, A.Y., Keller, J., Poussade, Y. and Batstone, D.J. (2011) Characterisation and Removal of Recalcitrants in Reverse Osmosis Concentrates from Water Reclamation Plants. Water Research, 45, 2415-2427.

https://doi.org/10.1016/j.watres.2011.01.024

[11] Pérez-González, A., Urtiaga, A.M., Ibáñez, R. and Ortiz, I. (2012) State of the Art and Review on the Treatment Technologies of Water Reverse Osmosis Concentrates. Water Research, 46, 267-283. https://doi.org/10.1016/j.watres.2011.10.046

[12] Benner, J., Salhi, E., Ternes, T. and von Gunten, U. (2008) Ozonation of Reverse Osmosis Concentrate: Kinetics and Efficiency of Beta Blocker Oxidation. Water Research, 42, 3003-3012. https://doi.org/10.1016/j.watres.2008.04.002

[13] Tang, F., Hu, H.-Y., Wu, Q.-Y., Tang, X., Sun, Y.-X., Shi, X.-L. and Huang, J.-J. (2013) Effects of Chemical Agent Injections on Genotoxicity of Wastewater in a Microfiltration-Reverse Osmosis Membrane Process for Wastewater Reuse. Journal of Hazardous Materials, 260, 231-237. https://doi.org/10.1016/j.jhazmat.2013.05.035

[14] Zhou, T., Lim, T.-T., Chin, S.-S. and Fane, A.G. (2011) Treatment of Organics in Reverse Osmosis Concentrate from a Municipal Wastewater Reclamation Plant: Feasibility Test of Advanced Oxidation Processes with/without Pretreatment. Chemical Engineering Journal, 166, 932-939. https://doi.org/10.1016/j.cej.2010.11.078

[15] Rautenbach, R. and Mellis, R. (1994) Waste Water Treatment by a Combination of Bioreactor and Nanofiltration. Desalination, 95, 171-188.

https://doi.org/10.1016/0011-9164(94)00012-3

[16] Li, K., Cheng, Y., Wang, J., Zhang, J., Liu, J., Yu, D., Li, M. and Wei, Y. (2016) Effects of Returning NF Concentrate on the MBR-NF Process Treating Antibiotic Production Wastewater. Environmental Science and Pollution Research, 23, 13114-13127. https://doi.org/10.1007/s11356-016-6467-x

[17] Schäfer, A.I. (2006) Nanofiltration-Principles and Applications. Elsevier, Oxford.

[18] Kappel, C., Kemperman, A.J.B., Temmink, H., Zwijnenburg, A., Rijnaarts, H.H.M. and Nijmeijer, K. (2014) Impacts of NF Concentrate Recirculation on Membrane Performance in an Integrated MBR and NF Membrane Process for Wastewater Treatment. Journal of Membrane Science, 453, 359-368. https://doi.org/10.1016/j.memsci.2013.11.023

[19] Vu, T.T.N., Montaner, M. and Guigui, C. (2017) Recycling of Reverse Osmosis Concentrates to the Membrane Bioreactor in the MBR-RO Process for Water Reuse: Effect on MBR Performances. Journal of Water Science, 30, 1-10. https://doi.org/10.7202/1040057ar

[20] Reid, E., Liu, X. and Judd, S.J. (2006) Effect of High Salinity on Activated Sludge Characteristics and Membrane Permeability in an Immersed Membrane Bioreactor. Journal of Membrane Science, 283, 164-171. https://doi.org/10.1016/j.memsci.2006.06.021

[21] Joss, A., Baenninger, C., Foa, P., Koepke, S., Krauss, M., McArdell, C.S., Rottermann, K., Wei, Y., Zapata, A. and Siegrist, H. (2011) Water Reuse: > 90\% Water Yield in $\mathrm{MBR} / \mathrm{RO}$ through Concentrate Recycling and $\mathrm{CO}_{2}$ Addition as Scaling Control. Water Research, 45, 6141-6151. https://doi.org/10.1016/j.watres.2011.09.011

[22] Li, C., Cabassud, C. and Guigui, C. (2015) Effects of Carbamazepine in Peak Injec- 
tion on Fouling Propensity of Activated Sludge from a MBR Treating Municipal Wastewater. Journal of Membrane Science, 475, 122-130.

https://doi.org/10.1016/j.memsci.2014.10.017

[23] Parkhurst, D.L. and Appelo, C.A.J. (1999) User's Guide to PHREEQC (Version 2): A Computer Program for Speciation, Batch-Reaction, One-Dimensional Transport, and Inverse Geochemical Calculations (USGS Numbered Series No. 99-4259), Water-Resources Investigations Report. U.S. Geological Survey: Earth Science Information Center, Open-File Reports Section [Distributor].

[24] Olson, B.J.S.C. and Markwell, J. (2007) Assays for Determination of Protein Concentration. In: Coligan, J.E., Dunn, B.M., Speicher, D.W. and Wingfield, P.T., Eds., Current Protocols in Protein Science, John Wiley \& Sons, Inc., Hoboken, 3.4.1-3.4.29.

[25] Dreywood, R. (1946) Qualitative Test for Carbohydrate Material. Industrial Engineering Chemistry and Analytical Edition, 18, 499.

https://doi.org/10.1021/i560156a015

[26] Li, C., Cabassud, C., Reboul, B. and Guigui, C. (2015) Effects of Pharmaceutical Micropollutants on the Membrane Fouling of a Submerged MBR Treating Municipal Wastewater: Case of Continuous Pollution by Carbamazepine. Water Research, 69, 183-194. https://doi.org/10.1016/j.watres.2014.11.027

[27] Pinto, O.A., Tabaković, A., Goff, T.M., Liu, Y. and Adair, J.H. (2011) Calcium Phosphate and Calcium Phosphosilicate Mediated Drug Delivery and Imaging. In: Prokop, A., Ed., Intracellular Delivery, Springer, Dordrecht, 713-744. https://doi.org/10.1007/978-94-007-1248-5 23

[28] Tansel, B. (2012) Significance of Thermodynamic and Physical Characteristics on Permeation of Ions during Membrane Separation: Hydrated Radius, Hydration Free Energy and Viscous Effects. Separation and Purification Technology, 86, 119-126. https://doi.org/10.1016/j.seppur.2011.10.033

[29] Asano, T. and Metcalf \& Eddy, Inc. (2007) Water Reuse: Issues, Technology, and Applications. McGraw-Hill, New York.

[30] Akbari, A., Remigy, J.C. and Aptel, P. (2002) Treatment of Textile Dye Effluent Using a Polyamide-Based Nanofiltration Membrane. Chemical Engineering and Processing. Process Intensification, 41, 601-609. https://doi.org/10.1016/S0255-2701(01)00181-7

[31] Ball, J.W. and Nordstrom, D.K. (1991) User's Manual for WATEQ4F, with Revised Thermodynamic Data Base and Text Cases for Calculating Speciation of Major, Trace, and Redox Elements in Natural Waters. https://doi.org/10.3133/ofr91183 


\section{Nomenclature}

$\rho \quad$ Volumetric mass density $\left(998 \mathrm{~kg} \cdot \mathrm{m}^{-3}\right.$ at $\left.22^{\circ} \mathrm{C}\right)$

$\mu \quad$ Viscosity of solution $\left(0.9544 \mathrm{mPa}\right.$ s at $\left.22^{\circ} \mathrm{C}\right)$

$\varepsilon_{s p} \quad$ Spacer porosity (0.8)

$\Delta \pi \quad$ Osmosis pressure gradient across the membrane (bar)

$\Delta P \quad$ Transmembrane pressure (bar)

$\pi_{m} \quad$ Osmosis pressure at the membrane surface (bar)

$\pi_{p} \quad$ Osmosis pressure in RO permeate side (bar)

$A_{m} \quad$ Surface area of membrane $\left(\mathrm{m}^{2}\right)$

AOPS Advanced oxidation processes

$C F \quad$ Concentration factor

$C_{c} \quad$ Concentration of an indicator in $\mathrm{RO}$ concentrate $\left(\mathrm{mg} \cdot \mathrm{L}^{-1}, \mathrm{~mol} \cdot \mathrm{L}^{-1}\right)$

$C_{f} \quad$ Concentration of an indicator in $\mathrm{RO}$ inflow $\left(\mathrm{mg} \cdot \mathrm{L}^{-1}, \mathrm{~mol} \cdot \mathrm{L}^{-1}\right)$

$C_{m} \quad$ Concentration of an indicator at membrane surface $\left(\mathrm{mg} \cdot \mathrm{L}^{-1}, \mathrm{~mol} \cdot \mathrm{L}^{-1}\right)$

$C_{p} \quad$ Concentration of an indicator in $\mathrm{RO}$ permeate $\left(\mathrm{mg} \cdot \mathrm{L}^{-1}, \mathrm{~mol} \cdot \mathrm{L}^{-1}\right)$

$C O D \quad$ Chemical oxygen demand

$D_{i} \quad$ Diffusivity of ion $i$ in water $\left(\mathrm{m}^{2} \cdot \mathrm{s}^{-1}\right)$

DIC Dissolved inorganic carbon

$d_{H} \quad$ Hydraulic diameter for a rectangular channel

$H \quad$ Spacer thickness $(0.00063 \mathrm{~m})$

IAP Ionic activity product

$J \quad$ Membrane flux $\left(\mathrm{L} \cdot \mathrm{h}^{-1} \cdot \mathrm{m}^{-2}\right)$

$k_{i} \quad$ Mass transfer coefficient of ion $i\left(\mathrm{~m} \cdot \mathrm{s}^{-1}\right)$

$K_{s p} \quad$ Solubility product constant

Lp Initial permeability of virgin membrane $\left(\mathrm{L} \cdot \mathrm{h}^{-1} \cdot \mathrm{m}^{-2} \cdot \mathrm{bar}^{-1}\right)$

MBR Membrane bioreactor

$M F \quad$ Microfiltration

$M W C O \quad$ Molecular weight cut-off

NF Nanofiltration

NPOC Non-purgeable organic carbon

$Q_{c} \quad$ Flow rate of $\mathrm{RO}$ concentrate $\left(\mathrm{L} \cdot \mathrm{h}^{-1}\right)$

$Q_{f} \quad$ Flow rate of RO inflow $\left(\mathrm{L} \cdot \mathrm{h}^{-1}\right)$

$Q_{p} \quad$ Flow rate of $\mathrm{RO}$ permeate $\left(\mathrm{L} \cdot \mathrm{h}^{-1}\right)$

$P_{c} \quad$ Pressure in $\mathrm{RO}$ concentrate side (bar)

$P_{f} \quad$ Pressure in RO feed side (bar)

$P_{p} \quad$ Pressure in $\mathrm{RO}$ permeate side (bar)

$R_{o b s} \quad$ Observed retention capacity (\%)

$R \quad$ Universal gas constant $\left(8.3145 \mathrm{~J} \cdot \mathrm{mol}^{-1} \cdot \mathrm{K}^{-1}\right)$.

Re Reynolds number

RO Reverse osmosis

Sc Schmidt number

Sh Sherwood number

SI Saturation index 
SMPS Soluble microbial products

$S R T \quad$ Solids retention time

$T \quad$ Absolute temperature (K)

TOC Total organic carbon

$U \quad$ Tangential velocity of $\mathrm{RO}$ concentrate $\left(\mathrm{m} \cdot \mathrm{s}^{-1}\right)$

UVA Ultraviolet absorbance

UF Ultrafiltration

$V_{1} \quad$ Valve of RO concentrate side

WWTPS Wastewater treatment plants

$Z_{i} \quad$ Valency of ion $i$ 


\section{Supplementary Information}

Table S1. Operating conditions of the MBR pilot.

\begin{tabular}{|c|c|}
\hline Net flux of MBR permeate & $9.8 \mathrm{~L} \cdot \mathrm{h}^{-1} \cdot \mathrm{m}^{-2}$ \\
\hline Filtration/relaxation cycles & $8 \mathrm{~min} / 4 \mathrm{~min}$ \\
\hline Solid retention time (SRT) & 45 days \\
\hline Hydraulic retention time (HRT) & $18.4 \mathrm{~h}$ \\
\hline Aerobic MLSS & $7.7 \pm 0.8 \mathrm{~g} \cdot \mathrm{L}^{-1}$ \\
\hline Aeration & With large air bubbles at a flow rate of $1.5 \mathrm{~L} \cdot \mathrm{min}^{-1}$ \\
\hline Manufacturer & Hydranautics \\
\hline Material & Polyamide \\
\hline Average pore diameter $(\mathrm{nm})$ & Not applicable \\
\hline $\mathrm{Na}^{+}$rejection (\%) & 96.5 \\
\hline $\operatorname{MWCO}\left(\mathrm{g} \cdot \mathrm{mol}^{-1}\right)^{\mathrm{a}}$ & $<100$ \\
\hline Surface roughness $(\mathrm{nm})$ & 30.0 \\
\hline Membrane charge & Negative \\
\hline Surface charge $(\mathrm{mV})$ & $\sim 20$ \\
\hline
\end{tabular}

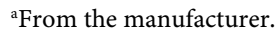

\section{Calculation of mass transfer coefficient of ions $i\left(k_{i}\right)$}

The following equations could be used to estimate $k_{i}$ values (Hoek et al., 2008).

$$
\begin{gathered}
k_{i}=S h \frac{D_{i}}{d_{H}}=0.065 \operatorname{Re}^{0.875} S c^{0.25} \frac{D_{i}}{d_{H}} \\
\operatorname{Re}=\frac{\rho U d_{H}}{\mu} \\
S c=\frac{\mu}{\rho D_{i}} \\
d_{H}=2 \varepsilon_{s p} H
\end{gathered}
$$

where $S h$ is the Sherwood number. Re is the Reynolds number. $S c$ is the Schmidt number. $D_{i}$ is the diffusivity of ion $i$ in water $\left(\mathrm{m}^{2} \cdot \mathrm{s}^{-1}\right) . U$ is the tangential velocity, equal to $0.18 \mathrm{~m} \cdot \mathrm{s}^{-1} \cdot \rho$ is the volumetric mass density $\left(998 \mathrm{~kg} \cdot \mathrm{m}^{-3}\right.$ at $\left.22^{\circ} \mathrm{C}\right) \cdot d_{H}$ is the hydraulic diameter of a rectangular channel. $\mu$ is the viscosity of the solution $\left(0.9544 \mathrm{mPa} \cdot \mathrm{s}\right.$ at $\left.22^{\circ} \mathrm{C}\right) . H$ is the spacer thickness $(0.00063 \mathrm{~m}) . \varepsilon_{s p}$ is the spacer porosity $(0.8)$. Throughout the RO process, the operating temperature was kept at $22^{\circ} \mathrm{C} \pm 1{ }^{\circ} \mathrm{C}$, so the viscosity, density, and diffusivity of the feed solution were constant here. The $k_{i}$ values of ion $i$ are summarized in Table S3.

Based on the $k_{i}$ value and the ionic concentration measured in both the RO permeate $\left(C_{p}\right)$ and bulk RO concentrate $\left(C_{c}\right)$, the concentration of each ion at the RO membrane surface $\left(C_{m}\right)$ was calculated before and during RO concen- 
trate addition, as shown in Table S4. The $C_{m}$ value of each ion increased with RO concentrate recycling. Moreover, the $C_{m}$ value of each ion was slightly higher than $C_{\mathcal{o}}$ which confirmed that concentration polarization occurred. The ratio of the ionic concentration between at the RO membrane surface and in the bulk RO concentrate $\left(C_{m} / C_{c}\right)$ kept almost constant before or during RO concentrate recycling.

\section{Concentration profile of COD}

The concentration profile of chemical oxygen demand (COD) was similar to the NPOC curve, as can be seen in Figure S1. After 14 days of RO retentate addition, COD concentration increased by a factor of 1.4 in MBR permeate (from $25 \pm 2 \mathrm{mg} \cdot \mathrm{L}^{-1}$ to $34 \pm 2 \mathrm{mg} \cdot \mathrm{L}^{-1}$ ), of $1.7 \mathrm{in} \mathrm{RO}$ concentrate (from $61 \pm 2 \mathrm{mg} \cdot \mathrm{L}^{-1}$ to $\left.105 \pm 2 \mathrm{mg} \cdot \mathrm{L}^{-1}\right)$. In RO permeate, the concentration of COD remained almost constant throughout the experiment, near to the detection limit, which also matched a fact of the overall retention capacity remaining above $94 \%$ over the

Table S3. Diffusion coefficient, Reynolds Number, Schmidt Number, Sherwood Number, and transfer coefficient of different ions.

\begin{tabular}{cccccccccc}
\hline $\mathrm{Re}=191$ & $\mathrm{Cl}^{-}$ & $\mathrm{N}^{-\mathrm{NO}_{3}^{-}}$ & $\mathrm{HCO}_{3}^{-}$ & $\mathrm{SO}_{4}^{2-}$ & $\mathrm{P}-\mathrm{PO}_{4}^{3-}$ & $\mathrm{Na}^{+}$ & $\mathrm{K}^{+}$ & $\mathrm{Mg}^{2+}$ & $\mathrm{Ca}^{2+}$ \\
\hline$D_{i} \times 10^{10} \mathrm{~m}^{2} \cdot \mathrm{s}^{-1 \mathrm{a}}$ & 20.32 & 19.02 & 11.85 & 10.65 & 8.24 & 13.34 & 19.57 & 7.06 & 7.92 \\
$S c$ & 471 & 503 & 807 & 898 & 1161 & 717 & 489 & 1355 & 1207 \\
$S h$ & 29.8 & 30.3 & 34.1 & 35.0 & 37.4 & 33.1 & 30.1 & 38.8 & 37.7 \\
$k_{i} \times 10^{5} \mathrm{~m} \cdot \mathrm{s}^{-1}$ & 6.01 & 5.72 & 4.01 & 3.70 & 3.05 & 4.38 & 5.84 & 2.72 & 2.96 \\
\hline
\end{tabular}

${ }^{a}$ The diffusion coefficients of ionic species were obtained from [2] and [3].

Table S4. Ionic concentration at the RO membrane surface before and during RO concentrate recirculation

\begin{tabular}{|c|c|c|c|c|c|c|c|c|c|}
\hline \multirow{3}{*}{ Ions } & \multicolumn{4}{|c|}{ Before recycling } & \multicolumn{4}{|c|}{ During recycling (Stage 3) } & \multirow{3}{*}{$\begin{array}{r}\text { average } \\
C_{m} / C_{c}{ }^{\mathrm{a}}\end{array}$} \\
\hline & \multicolumn{2}{|c|}{$\begin{array}{c}\text { Hour } 5 \\
\text { (end of Stage 1) }\end{array}$} & \multicolumn{2}{|c|}{$\begin{array}{c}\text { Day } 3 \\
\text { (end of Stage 2) }\end{array}$} & \multicolumn{2}{|c|}{$\begin{array}{l}\text { Day } 7 \\
\text { (after } 4 \mathrm{~d} \text { of } \\
\text { recycling) }\end{array}$} & \multicolumn{2}{|c|}{$\begin{array}{l}\text { Day } 14 \\
\text { (after } 11 \mathrm{~d} \text { of } \\
\text { recycling) }\end{array}$} & \\
\hline & $C_{m}$ & $C_{c}$ & $C_{m}$ & $C_{c}$ & $C_{m}$ & $C_{c}$ & $C_{m}$ & $C_{c}$ & \\
\hline $\mathrm{Cl}^{-}$ & 556 & 534 & 627 & 602 & 1220 & 1178 & 1740 & 1689 & 1.04 \\
\hline $\mathrm{N}-\mathrm{NO}_{3}^{-}$ & 13 & 12 & 13 & 12 & 15 & 15 & 15 & 15 & 1.03 \\
\hline $\mathrm{HCO}_{3}^{-}$ & 95 & 89 & 101 & 95 & 121 & 115 & 126 & 121 & 1.05 \\
\hline $\mathrm{SO}_{4}^{2-}$ & 164 & 154 & 170 & 156 & 201 & 186 & 226 & 211 & 1.08 \\
\hline $\mathrm{P}-\mathrm{PO}_{4}^{3-}$ & 0.89 & 0.84 & 0.85 & 0.80 & 2.9 & 2.7 & 3.5 & 3.3 & 1.06 \\
\hline $\mathrm{Na}^{+}$ & 688 & 651 & 725 & 687 & 777 & 742 & 797 & 766 & 1.05 \\
\hline $\mathrm{K}^{+}$ & 34 & 32 & 34 & 33 & 45 & 44 & 51 & 50 & 1.03 \\
\hline $\mathrm{Mg}^{2+}$ & 16 & 15 & 16 & 15 & 22 & 21 & 28 & 26 & 1.07 \\
\hline $\mathrm{Ca}^{2+}$ & 203 & 187 & 209 & 193 & 240 & 225 & 301 & 284 & 1.07 \\
\hline
\end{tabular}

The average ratio of the ionic concentration at the membrane surface and in the bulk RO concentrate. 


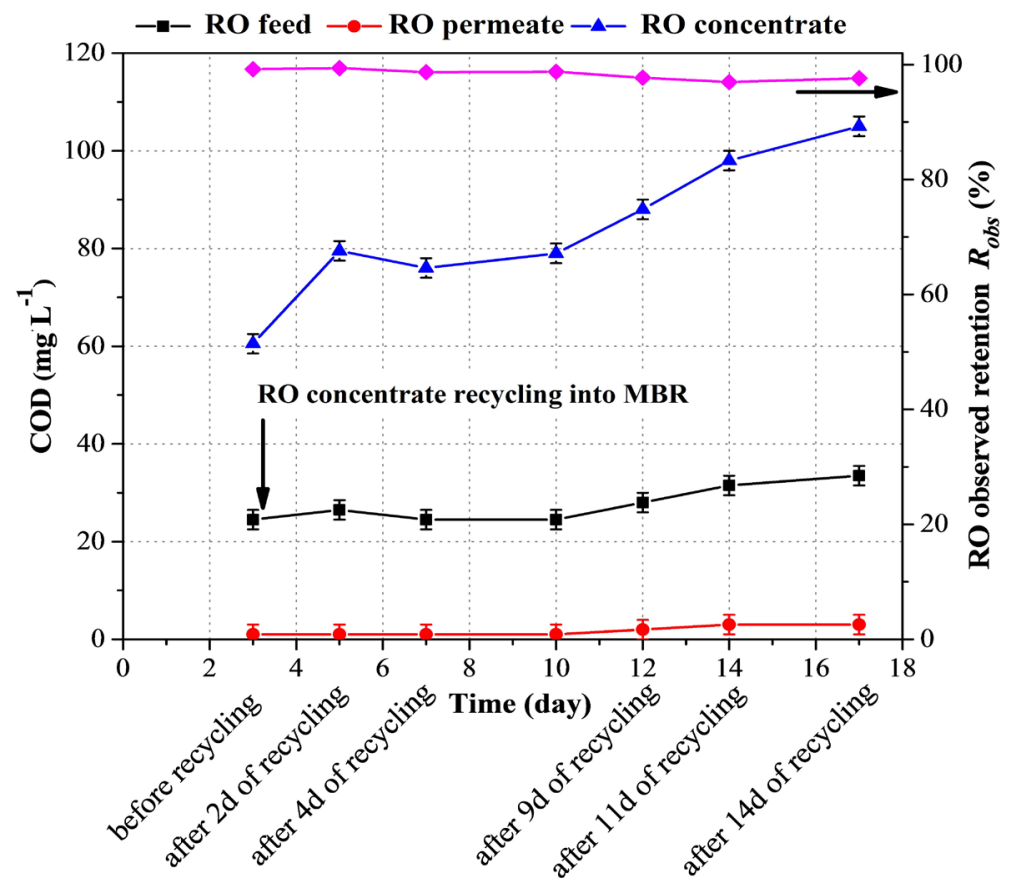

Figure S1. Variation of COD in RO flows with the recirculation of RO concentrate. Cross-flow velocity: $0.18 \mathrm{~m} \cdot \mathrm{s}^{-1} . \Delta P: \sim 7$ bar. CF: 3 .

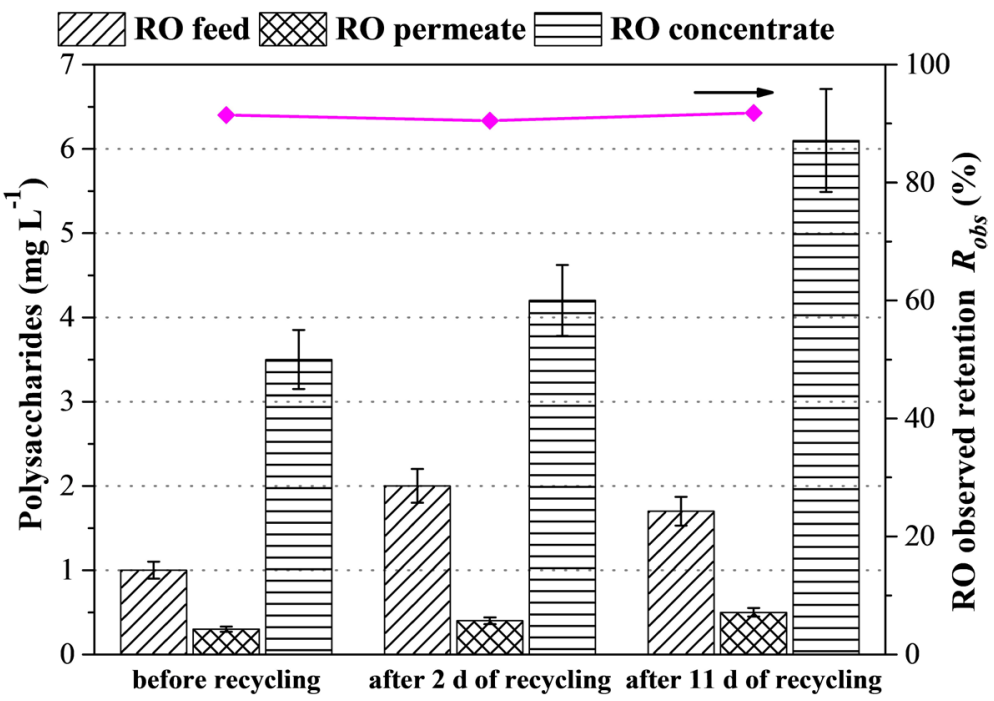

Figure S2. Concentration of polysaccharides in RO flows before and after RO concentrate recirculation. Cross-flow velocity: $0.18 \mathrm{~m} \cdot \mathrm{s}^{-1} . \Delta P: \sim 7$ bar. CF: $\sim 3$.

entire filtration experiment.

\section{References}

[1] Alturki, A.A., Tadkaew, N., McDonald, J.A., Khan, S.J., Price, W.E. and Nghiem, L.D. (2010) Combining MBR and NF/RO Membrane Filtration for the Removal of Trace Organics in Indirect Potable Water Reuse Applications. Journal of Membrane Science, 365, 206-215. https://doi.org/10.1016/j.memsci.2010.09.008

[2] Hoek, E.M.V., Allred, J., Knoell, T. and Jeong, B.-H. (2008) Modeling the Effects of Fouling on Full-Scale Reverse Osmosis Processes. Journal of Membrane Science, 
314, 33-49. https://doi.org/10.1016/j.memsci.2008.01.025

[3] Hoek, E.M.V., Allred, J., Knoell, T. and Jeong, B.-H. (2008) Modeling the Effects of Fouling on Full-Scale Reverse Osmosis Processes. Journal of Membrane Science, 314, 33-49. https://doi.org/10.1016/j.memsci.2008.01.025

[4] Lide, D.R. (2005) CRC Handbook of Chemistry and Physics, Internet Version 2005. CRC Press, Boca Raton. 